\title{
NOTES ON SOME MAMMALS OF THE COOKING LAKE HIGHLANDS, ALBERTA
}

E. OTTO HÖHN, Department of Physiology, University of Alberta, Edmonton, Alberta, T6G $2 \mathrm{H} 7$.

The Cooking Lake Highlands form a slightly elevated area, overlying a moraine of the same name, which lies to the east of Edmonton, extending to within a few miles of Tofield (see map). While in most of the Edmonton district the original aspen forest has been destroyed, an almost unbroken belt of poplar woods with a slight admixture of birch and spruce still extends over these highlands, from Elk Island National Park in the north to the Miquelon Lakes in the south and for a somewhat shorter distance east to west. The small acreage where I trapped small mammals to determine the species occurring locally lies within this area, and as I have owned it for twenty years, the observations reported below were made over that period. I have, however, also included reports of sightings of the larger and unmistakeable mammals by the district game warden at Ministik, Mr. Keith Williams, and other residents in the district, for these provide evidence of the occurrence of species one would not expect in so well settled an area near a large city. The fauna of this district will undoubtedly change as more of it gets broken up into acreages. Indeed, the very marked decrease of mule deer, formerly the dominant species of deer in this area, which has already taken place, is most probably due to increased human disturbance associated with his process.

Species are designated by the
English names used by Banfield in his Mammals of Canada.1

SHREWS: "Trapping", in cylindrical containers buried in the soil with the opening flush with the ground surface (small mammal traps, even when baited with bacon or dead mice, were not effective for shrews) on my acreage near Hastings Lake over four summers, gave the following results: MASKED SHREW: Evidently the most common species; apart from trapped specimens, occasional dead animals found. An intact corpse was found with the fleshless remains of one of these shrews plus those of a red-backed vole in a plastic tube containing oats which the animals had been unable to leave. Evidently one or both shrews had killed and eaten the vole and later one shrew had killed and eaten the other. ARCTIC SHREW: Six collected between 1972 and 1976 and one found dead the following year. Soper describes it as occurring in the transition zone in boreal "islands" but my animals were in ordinary poplar grove country, not in a boreal island. 4 This species is therefore apparently more generally distributed in the aspen parkland zone than his statement indicates. PIGMY SHREW: One of these very locally distributed shrews was collected in 1973.

LITTLE BROWN BAT: This is the only species of bat I observed (and 


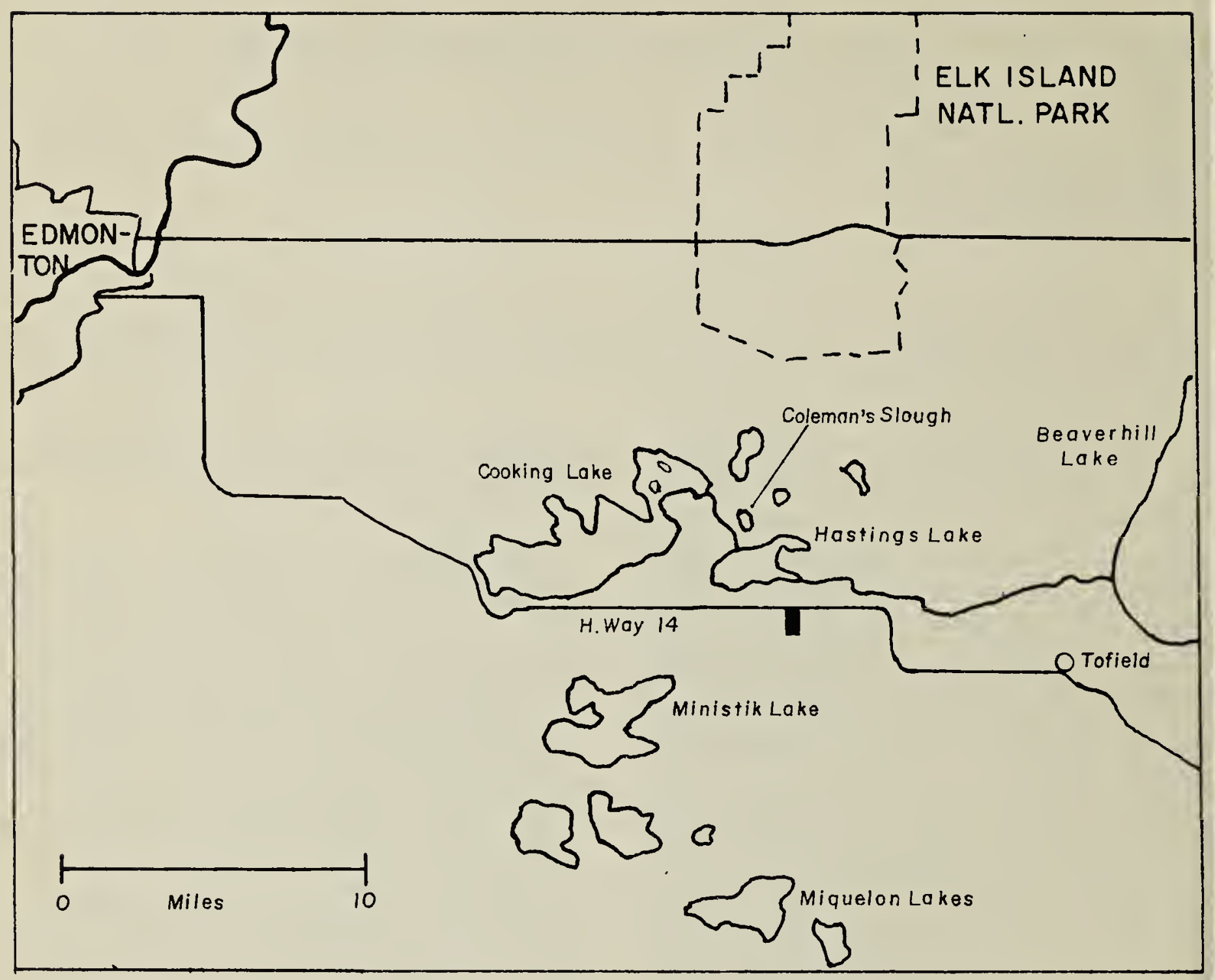

Figure 1: Sketch map of the Cooking Lake Highlands area acreage where small mammals were trapped shown in black.

collected) in the area; some roosted under rubberized shingles of our cottage near Hastings Lake.

SNOWSHOE HARE: Relatively scarce in the district compared to areas 100 miles further north; never more than one or at most two on our twenty acre acreage and sometimes none for several months.

WOODCHUCK: Scarce in this district; only one seen alive near Hastings Lake and the corpse of a melanistic one found.

FRANKLIN GROUND SQUIRREL: In my experience, scarce in the district. I have only seen two or three in twenty years of observation.

FLYING SQUIRREL: When knocking down a disused magpie nest in May 1975 , I flushed one from the lower part of the nest. It was not seen subsequently. Mr. F. Rourke of Hastings Lake sees flying squirrels on winter nights at his bird feeder fairly often and has seen a Great Horned Owl attempting to catch one (subsequent squeals later, when the animals were out of sight, suggested the owl had been successful).

MICE AND VOLES: Trapping on my acreage indicated that DEER MICE were by far the most abundant small rodent. These mice and once a HOUSE MOUSE were the only species which entered the cottage. GAPPER'S RED-BACKED VOLE was second in abundance. MEADOW VOLES were the least common of this group and seemed to prefer 
tuary in 1954. The hounds killed the coyotes but the wolf defended itself successfully and escaped. As wolves occur regularly about 120 miles north and west of the district, the local presence of a very occasional wanderer seems plausible.

RED FOX: Dekker has reported that foxes are now more frequently to be seen in the Edmonton region than formerly. ${ }^{2}$ However, they live mainly in the more open areas east of the district considered here. I have only seen one about Hastings Lake in 1977 and the Ministik game warden told me he had not seen any nor heard of any sightings.

BLACK BEAR: A member of the R.C.M.P. told me of seeing one at the garbage by his house one night in late 1973 or 1974 . These bears occur regularly about 120 miles from the district.

WEASELS: The LONG-TAILED WEASEL is evidently the most abundant of these weasels; with the two exceptions below, all weasels I have seen well enough to identify were of this species. I have never seen the SHORT-TAILED WEASEL in this district in life but trapped two (winter 1972 and 1977) on my acreage. I have only two observations of LEAST WEASELS; both in winter, in each case the animal was crossing a road in front of my car.

MINK: Soper does not include the area considered in his provinical distribution map of the mink, and though Banfield considers all of Alberta to be within its range, it is evidently scarce in this general area. ${ }^{4} 1$ It is, however, fairly frequently trapped in the Cooking Lake Highlands according to the Ministik game warden, and Mir. F. Rourke, who lives on the shore of Hastings Lake, sees mink on the lakeshore or swimming in the lake with some frequency. I saw one on a roac beside my acreage in Septembe 1972; the next day it was shot by neighbor who said it had killed some of his chickens.

LYNX: Since the district lies out side the area of distribution of this species as mapped by Soper and Banfield it is worth recording that ac cording to the Ministik game warder there is a moderate permanen population. 41 In years of "rabbit" crashes in areas further north, where the lynx is always more numerous, a in 1962 and 1972, greater number: were seen in the Cooking Lak highlands. Thus my wife and son sav one on our acreage in July 1962 and saw tracks of one in November 1972 I also saw the skin of one shot locall about this time and certain neigh bours reported seeing one of thes animals in the winter of 1972/73.

COUGAR: About 1975 there wa evidently at least one cougar an possibly more than one in th district. The owner of the Albert Game Farm received a number $c$ phone calls from farmers in the are from Fort Saskatchewan to Camros reporting sightings of cougars. Th callers wanted him to attempt to caf ture the animal as they feared attack on their cattle. A farmer's daughter a Cooking Lake gave me a convincin description of one she had seen i the open in summer, and severe other summer sightings were repo: ted to the Ministik game warder There have been no escapes $c$ cougars from the Alberta Gam Farm. The district lies 200 miles eas of the nearest area where cougar are considered to occur regularly.

MULE and WHITE-TAILED DEEF A marked change in the relativ abundance of these two species deer has taken place in this distric Up to about mid-century, the mul deer was the most common deer i 
his area. Soper does not list the white-tailed deer in his account of he mammals of Elk Island National Park and considered it a recent arrival in the district around the park. ${ }^{4}$ It now outnumbers the mule leer in the park in the ratio of 9:1 acording to the park warden, who pelieves that the original animals of he species entered the park by rawling under the fences. Keith also efers to the former prevalence of hule deer about New Sarepta, which es a little south of the district under onsideration. ${ }^{3}$ Up to the late 1950's, hy impression was that these two pecies of deer occurred in the fooking Lake highlands in roughly qual numbers, but in recent years nd at present I see only white-tailed eer, which are common. Neverpeless, the mule deer is, at least acording to the Ministik game warden, till to be found locally, perhaps only areas which have not yet been roken up into acreages. My only ecent sightings of single mule deer t Beaverhill Lake in 1976 and 1977 ere somewhat east of the area uner consideration.

ELK and MOOSE: Earlier I had onsidered that the elk and moose in is district reported to me from time time were probably escapes from Ik Island National Park. I now conder this improbable because I have een informed that no bison has ever scaped from the park, which iggests that its fences would also event elk and moose from leaving The representatives of these two ecies still found in the district are, erefore, most probably the remnant a presettlement, native population. heir continued presence is partly le to the fact that they are not legal ame in this area. Some moose are, wever, occasionally poached and, imals of both species are metimes taken legally on Crown land in this area by Indians. The local elk and moose are therefore not fully immune from hunting. While I have not seen any elk myself, the Ministik warden has seen a herd of 40 in the Black Foot forest reserve, an area almost as large as Elk Island National Park which lies between the southern portion of the park and the northeastern part of Cooking Lake and the north shore of Hastings Lake, and he knows of smaller numbers near his home. I have also been told of occasional local sightings by others.

Though rarely seen (my son and I have each seen only one in the Hastings Lake area), the finding of a cast-off antler, tracks and the reported sightings of country neighbours indicate a moderate local population. An individual who often flies a small plane over the district concludes on the basis of his observations that moose are actually fairly common in the area.

\section{Acknowledgements}

I am obliged to Mr. N. Panter, sometime curator of the Museum of the Department of Zoology of the University of Alberta, for tips on how to catch shrews, the loan of traps and help with small mammal identifications.

1BANFIELD, A. W. F., 1974. The Mammals of Canada. Univ. of Toronto Press.

2DEKKER, D., 1973. Red Foxes Make a Comeback in Central Alberta After Thirty Years. Blue Jay 31:43-44.

${ }^{3}$ KEITH, L. B., 1965. Early Notes on Wildlife from New Sarepta, Alberta. Can. Field Naturalist. 79:29-34.

4SOPER, J. D., 1951. The Mammals of Elk Island National Park, Alberta, Canada. Canada Dept. of Resources and Development, National Parks Branch, Canadian Wildlife Service, Ottawa, Wildlife Management Bulletin, Ser. 1. No. 3. 


\section{Don't poison our waterways.}

Poisoning algae, weeds and other aquatic nuisances can also kill useful water life and contaminate water supplies.

That's why it is against the law to apply biocides or pesticides to Saskatchewan surface water or shorelines except under carefully controlled and properly authorized conditions.

For illustrated information on Saskatchewan aquatic nuisances, alternative control methods and applications for authorized control procedures, write:

Saskatchewan Environment, Water Pollution Control Branch, 1855 Victoria Avenue, Regina, S4P 3V5.

or call

Provincial Inquiry Centre:

in Regina service district, 565-6291;

in Lloydminster and Creighton, ask operator for Zenith 0-8599;

elsewhere in Saskatchewan, (1 or 112) 800-0667-8755. 